\title{
Model for determining the load or carrying capacity of rivers and riverbanks for recreational use
}

\section{Modelo para la determinación de la carga o la capacidad de acogida de los ríos y riberas para uso recreativo}

\author{
I. Otero, A. Ezquerra, M. Navarra and P. Sendra ${ }^{1}$
}

\section{INTRODUCTION}

The use of natural spaces to satisfy the leisure demands of the Spanish public -mainly city-dwellers- has led to the utilisation of the shores of reservoirs and riverbanks for recreational purposes.

The key feature defining the recreational use of river spaces is the spontaneity of the users, who despite the availability of facilities and planned leisure activities and programmes, tend to frequent them on weekends and public holidays. This phenomenon was first observed in the 1970s (Urbiston, 1973) and became widespread in Spain after the period of development and the resulting surge in income and free time.

In 1989, Valenzuela Rubio pointed to the central role of water in the pursuit of outdoor activities, and carried out a number of studies on leisure spaces associated with water, focusing on the geographic area of Madrid (Valenzuela Rubio, 1989). There are records of the ordination and enhancement of riverbanks for recreational purposes since the 1920s, although they appear in a wide diversity of plans and projects and were very unevenly im-

\footnotetext{
${ }^{1}$ ACKNowledgemEnTs: We would like to thank the Interministerial Commission for Science and Technology (CICYT) in the Spanish Ministry of Education for their support for this research through the award of project N. PA -0037.
} 
plemented. Examples include "Playa de Madrid" ("Madrid beach") in 1932, or the first Madrid University Campus Project in 1927, involving the ordination of inland waters for recreational use.

These are exceptions, as official state-level regulations for recreational activities did not come into effect until the 1960s. However this in no way restricted the widespread development of these areas from that point on, when studies were applied from neighbouring countries with previous experience in the field (Homan and Bennett, 1973).

In the Madrid Region, the various forestry plans and the Madrid Integral Water Plan (www.madrid.org/es, 2013) have included a programme of Public and Recreational Use containing recommendations on issues and guidelines to be considered within a specific package of regulations governing public recreational use. These followed the Millennium Ecosystem Assessment, an international programme designed to respond to the needs of legislators, planners and the general public to understand how changes in ecosystems affect human wellbeing (Asah et al., 2012) in terms of the beneficial health effects of leisure and recreation in nature (Selin et al., 2009). Continental water ecosystems are essential for energy production, transport, leisure, tourism, and as a habitat for animals and plants (Convention on Biological Diversity, 2009, UNEP). Forest management plans have been developed with experts from disciplines such as forestry, botany, wildlife biology, catchment management, water resources, cultural heritage and recreation planning, in consultation with the public. The planning process is based on information on the uses and values of the forest (natural, cultural, social, productive and economic). The management plans are also based on biological, social and cultural data from statements on resources, uses and values. The 2000-2019 Madrid Region forestry plan contains a section on public recreational use and environmental education which proposes the creation of an integrated system of recreational areas, and includes recommendations for subjects and guidelines that should be considered within a specific package of regulations for public recreational use. Ecosystem services are a frequent subject of debate between legislators and the protectors of such sites (Kline, 2009). The ecosystem sector is also currently the fastest growing in terms of tourism, with a $20 \%$ increase in global expenditure (TIES, 2006).

The general use of natural spaces for tourism and recreation has a series of impacts on the environment and the socio-economic setting wherever they are located, and the study of these sites has evolved through various stages.

These impacts have mainly been expressed in terms of the supply-demand relationship, but must also include the concept of "carrying capacity" or "load 
capacity", to take into account the critical issue of conservation. The idea that load capacity can be increased through marketing, new infrastructure, upgrading products, or offering new leisure and recreational activities is likely to be met with resistance by many outdoor recreational managers. Capacity assessments are designed to establish acceptable impact limits and decide whether additional demand can be accommodated. Although the absence of growth may signal that limits have been met or exceeded, it also points to the need for management measures to bring impacts back in line with acceptable standards. New marketing efforts, infrastructure development, product upgrades, and expanded leisure offerings should only be undertaken if they can potentially decrease impacts from recreation and tourism. For example, researchers seek to prohibit current uses that are causing unacceptable impacts, and replace them with less detrimental activities.

The debate on the limits of growth is not new, and has been around since 1930 in the case of tourism and leisure (Saveriades, 2000). In 1960 the concept of load capacity was already in use in research into outdoor recreational spaces (Manning et al., 1999).

This concept is conventionally defined as "the maximum number of visitors that an area can sustain without any unacceptable deterioration in the physical environment and without substantially impinging on the users' satisfaction" (Prato, 2001).

A similar definition is used by the World Tourism Organisation: "The maximum number of people that may visit a tourist destination at the same time, without causing destruction of the physical, economic, socio-cultural environment and an unacceptable decrease in the quality of visitors' satisfaction". Robert Manning (2001) subsequently defined carrying capacity and suggests that it can be quantified and managed by formulating indicators and quality standards. Quality indicators are measurable, manageable variables that define the quality of visitor experiences and natural/cultural resources. Quality standards define the minimum acceptable level of indicator variables. Once indicators and standards of quality have been formulated, indicator variables are monitored, and management action is undertaken to maintain quality standards. This approach to carrying capacity is central to contemporary park and outdoor recreational planning frameworks, including limits of acceptable change and visitor impact management, and has been incorporated into Visitor Experience and Resource Protection (VERP), a framework designed by the National Park Service, USA, to manage carrying capacity in the national park system.

Since 1990, carrying capacity has been replaced by sustainability in the area of recreation and leisure. 
Sustainability (Macbeth, 2005) denotes the complex political concept associated to limited growth, although steering clear of the idea of limits due to the possible implications for economic development.

Both concepts establish certain "limits" for use which are extremely difficult to define when formulating models and assessments (Saarinen, 2006).

The study of limits within the concept of load or carrying capacity has a long tradition in biology, forestry, sociology and geography (McCool and Lime, 2001), and specific cases have been analysed at certain points in protected areas (Garrigós et al., 2004). The study by Saveriades in 2000 focuses on the biophysical thresholds of the resources, and other examples provide figures on the quality of the recreational experience. This case study explores how the foundational components of carrying capacity (formulating indicators and standards, monitoring, and adaptive management) are being applied in an increasing number of fields of environmental and natural resources to address the urgent need for sustainability. Parks and Carrying Capacity is an important new work for faculty, graduate and undergraduate students, researchers in outdoor recreation, park planning and management, and natural resource conservation and management, as well as for professional planners and managers working with park and non-governmental outdoor recreationrelated agencies (Manning, 2007).

Load capacity and sustainability are not mutually incompatible (Navarro Jurado et al., 2012). Both concepts stress the need to limit the growth of tourism and the use of outdoor spaces, and to establish what are considered to be acceptable changes to the physical and social environments (Salerno et al., 2013).

The most challenging task is to design a methodology that objectively indicates the limits to ensure the conservation of these spaces.

The managers of these natural resources require a method that allows them to estimate the point beyond which the ecosystem enters an irreversible downturn, as their objective is to maintain and provide a competitive and sustainable recreational space. A sustainable space can also be made more competitive (Ritchie and Crouch, 2004), which calls for a study of the load capacity of areas used for recreational purposes.

The work of Navarro Jurado et al. (2012) revives the debate on the limits of growth in tourist destinations, and seeks solutions to the main drawbacks in order to contribute to the sustainable management of protected areas.

Butler (2006) proposes a dynamic model of limits which depends on how the space adapts to new situations; for example by increasing its load capacity through marketing, new infrastructures or upgrading its products, or -in our case- offering new leisure and recreational activities. For example, the ab- 
sence of growth may signal that the limit has already been reached, and further growth may require new products which can be materialised through participation by the interested sectors (Hughes, 1995).

Ecosystem services are a frequent subject of debate between legislators and the protectors of such sites (Kline, 2009). One example of an ordination plan for natural resources in Spain is PORN, the planning instrument for the Sierra de Guadarrama mountains, a territory in the Madrid Region. Its guiding principles are the conservation and improvement of the environment, and particularly the preservation of the quality of life and the traditional activities of the communities in the area. Its aims include particularly orienting and regulating the use and activities permitted in the various areas within the ordination zone by establishing guidelines and regulations to guarantee compatibility with protection and conservation (www.madrid.org, 2014). Similar goals are pursued by the programmes and initiatives of the Tennessee Department of the Environment, which seek to protect human health and the environment and support economic development and quality of life through education, outreach and effective enforcement of state and federal environmental laws; it also manages the award-winning Tennessee State Parks system (http://www. tennessee.gov/environment/, 2014). At the worldwide level, strategic target D in the UNEP's biodiversity plan is to increase ecosystem services, while target $E$ is to improve their management and capacity through public participation, taking into account the preservation of ecosystems as stated in strategic target D (CDB, 2009).

\section{MATERIALS AND METHODS}

\subsection{Aim and Methodology}

The aim of the work described in the present article is to design a methodology to determine the load or carrying capacity of rivers and river banks for recreational use in terms of their function, assimilation and recovery, all within an environmental and scenic context.

This general objective consists of a series of specific steps to design a method that considers carrying capacity as part of the planning process.

The methodology has the following highlights: it analyses the environmental variables for a series of specific recreational activities, namely picnicking, swimming, sailing, horse-riding, fishing, nature observation, camping; it considers natural variables such as attractiveness, functional capacity, assimilation and recovery capacity; and cultural variables such as regulations and user 
characteristics. It can be applied to all types of rivers. The structure of its database facilitates automatic processing. It enables different rivers or different sections of river to be compared.

The methodology is summarised in the chart in Figure 1.

FIGURE 1:

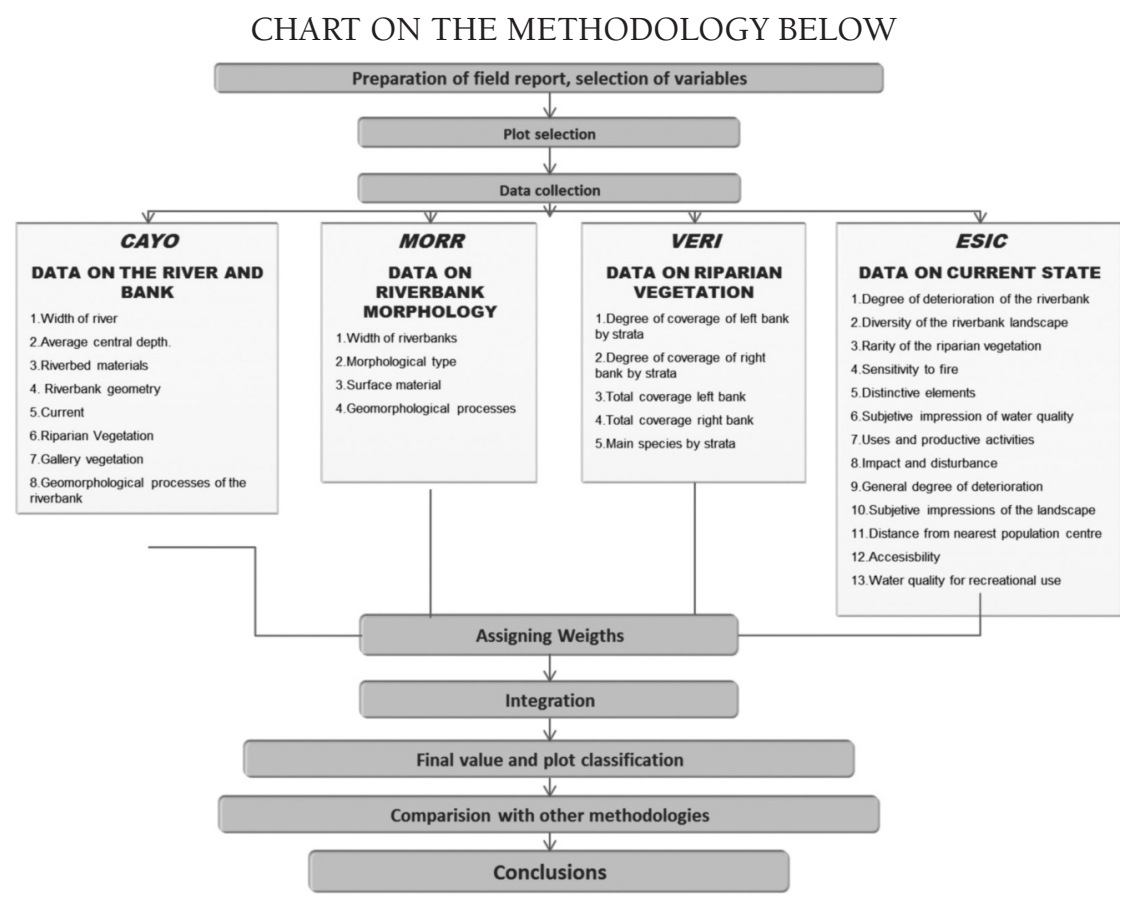

Origin: Own production.

\subsection{Study area}

The methodology was verified by application to the Madrid Region (Spain), and specifically to thirteen rivers:

Alberche, Aulencia, Cofio, Guadalix, Guadarrama, Henares, Jarama, Lozoya, Manzanares, Perales, Tajo, Tajuña, and Torote.

The study area was divided into the three classic physiographical areas in the Madrid Region, as follows:

- MOUNTAIN AREA: Lozoya valley, Sierra de Guadarrama and southern slope of the Cuerda Larga, Sierra Sur, Alberche river basin. 
- FOOTHILLS: Countryside, northeast section of Raña and Sagra and the area of metropolitan influence.

- EVAPORITIC: Plains and southwest section of Raña and Sagra.

\subsubsection{Lozoya valley}

Area characterised by the presence of reservoirs, representing a broad extension of banks and shores.

The presence of small towns and villages means there are several scattered waste disposal points.

Pressure from urban development for second homes due to its high environmental quality. This has led to increased recreational use and the installation of infrastructures associated with these activities such as campsites, paths, improvised parking areas and so on.

\subsubsection{Sierra del Guadarrama and southern slope of the Cuerda Larga.}

Presence of reservoirs, with regulated flow, and a marked decrease in this flow downstream.

Presence of solid urban waste and quarries with a significant visual impact.

Considerable urban development for second homes -particularly in the Guadarrama river basin- has led to the proliferation of waste disposal points. There is considerable pressure on rivers and riverbanks from population centres, and particularly in the section of the Guadarrama river on its way through Collado Villalba.

The riverbanks are subject to pressure due to their use for leisure and recreation. In other words, social pressure places a strain on natural, physical and biological resources, and on social aspects such as aesthetic appeal.

\subsubsection{Sierra Sur. Alberche River Basin}

The rivers run through grazing lands, rock-rose thickets and forests of black pine, stone pine and holm oak.

Good state of the riverbanks with a series of isolated waste disposal points, particularly on the right shore of the San Juan reservoir. 


\subsubsection{Countryside}

The typology of the banks and shores is as follows: in the upper sections, large extensions of un-irrigated land and open holm-oak forests. In the section where the river descends, the banks are more pronounced and the features the same but more deteriorated. On quaternary areas, riparian vegetation with galleries of herbaceous vegetation.

There are signs of waste disposal points, gravel pits and other productive activities, in addition to a degree of urban pressure.

There are some recreational zones close to road intersections, with paths, picnic areas, car parks and so on.

\subsubsection{Raña and Sagra (Northeast And Southwest)}

The banks of the Jarama and Henares rivers as they enter the Madrid Region have galleries and thickets set in an agricultural landscape, both rainfed and irrigated, with no trees in their riparian vegetation.

Extraction operations proliferate along some sections of the Jarama river.

There are leisure areas in wooded spaces along the banks of the river.

\subsubsection{Plain}

The Jarama and Tajo rivers run through agricultural landscapes, particularly irrigated lands. The Jarama has no thickets or galleries affected by gravel pits; however the Tajo flows through broad areas of galleries and thickets where the impact of gravel pits is limited.

The other river sections flow through agricultural areas with no thickets and galleries.

\subsubsection{Metropolitan influence}

This affects the Jarama, Manzanares, and Henares rivers where there is a proliferation of waste disposal points and debris, extraction of aggregates, refuse dumps, and occupation for urban and industrial uses. All this, together with the impact of their use for agriculture, produces a decline in the few remaining remnants of galleries.

See Figure 2. 


\section{FIGURE 2}

THE STUDY AREA DIVIDED INTO THE THREE CLASSIC PHYSIOGRAPHICAL AREAS IN THE MADRID REGION

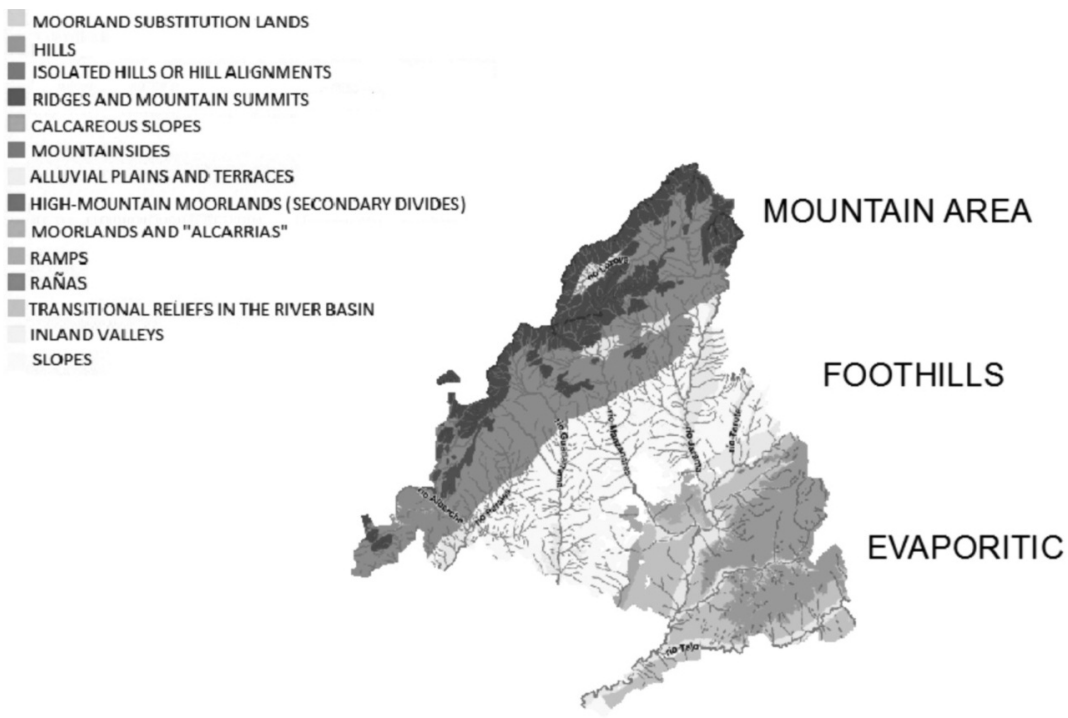

Fuente: www.madrid.org

\subsection{Selection of variables and data collection}

The first step in building the model -based on the scientific literature on the subject mentioned in the introduction, the authors' own experience, and the plans and programmes for public recreational use in the Madrid Region- was to select a series of environmental characteristics grouped into four basic categories:

- Data on the river and riverbank (CAYO). Width, depth, riverbed materials, geometry of the banks, current, vegetation (type and abundance).

- Data on the riverbank morphology (MORR). Morphology: width, morphological type, surface material, vegetation, degree of coverage and species inventory.

- Data on the riparian vegetation (VERI). Width, height, species inventory, rarity, degree of deterioration, diversity of plant landscape, sensitivity to fire.

- Data on the current state (ESAC). Singular natural and artificial points, subjective impression of water quality, uses and exploitation of river and 
banks, impacts and disturbances, geomorphological processes, general degree of deterioration, viewshed, subjective impression of the landscape, distance from population centre, accessibility, water quality.

Each one of these categories itself includes a series of variables, as shown in Figure 1.

Each variable is subdivided into a series of sub-categories to ensure proper representation of the variability of the environment.

This basic environmental information used to calculate the carrying capacity for recreation of the various spaces in the study (the 103 plots selected) is recorded in a field report which includes all the differentiated variables and categories (see the table in the following section). We have considered recreational use for the activities of picnicking, swimming, sailing, fishing, horse riding, nature observation, walking and camping.

Each of these activities requires particular characteristics apart from vegetation and morphology aspects. Information is necessary on other data affecting these and other recreational activities such as water quality, accessibility, singular points, uses and exploitation of the river and the bank, geometry of the banks, and so on. Most of these data were collected in the field. Others, such as water quality indices, sensitivity to fire and vegetation rarity were compiled by means of desk research. The first was established based on the threshold values that allow or prevent the recreational use of the water, and the rest by using the map of plant formations from the Madrid Region.

\subsection{Sampling Data collection}

The fieldwork was done by a random sampling to select 121 plots along the 13 rivers in the Madrid Region mentioned in the previous section; these points were materialised in areas of $50 \mathrm{~m}$ long by $50 \mathrm{~m}$ wide for both banks of the river.

The various plots in the sample were grouped into the three main areas differentiated for this study (see map), as they each had distinct characteristics and problems, as described in the previous section.

The data was collected in spring, between April and June 2012, randomly.

The field inventory was verified and supplemented with existing data (mainly from the Madrid Integral Water Plan (PIAM) www.madrid.org/cs).

103 field reports were completed out of the 121 plots selected, as described below. We were unable to collect data in the other plots as these were on private estates with restricted access, which are not necessary to our research. 


\subsection{Assigning weights}

A questionnaire on the variables and their categories was carried out among professionals and students in the field of environment in order to establish their relative weight, and indicating their contribution to the final value of the load or carrying capacity.

This anonymous questionnaire also requested additional data on the observers -such as age, education level and gender- for any possible subsequent analyses.

The ultimate aim of the questionnaire is for the respondent to assess, on a quantitative scale, the magnitude and importance of each variable and its categories.

The sample size in this study, determined according to the number of questionnaires needed for an error (d) of less than $10 \%$ and a variance $(\sigma)$ of 0.5 , is 97 questionnaires.

$\sigma=0,5$

$\mathrm{d}=0.1$

$1-\alpha=0.95$

$1-\alpha / 2=0.975$

Z1 $-\alpha / 2=1.96$. (Normality, using the Gaussian table)

$$
n=\left(\frac{\sigma \cdot Z_{1-\alpha / 2}}{d}\right)^{2}=\left(\frac{0,5.1,96}{0,1}\right)^{2}=96.4=97 \text { questionnaires }
$$

A total of 103 questionnaires were taken. 162 points were randomly chosen on the map of the Madrid Region at the scale of 1:200.000, separated by a distance of about $2 \times 2 \mathrm{~cm}$.

All points that lay within an urban area in the main population centres in the Madrid Region were discarded. Any points that were very close together were also eliminated. The final result was 212 points, which were materialised in plots of 50 $\mathrm{m}$. We were unable to collect data on some of these. The final inventory was: SIERRA Alberche: 5, Aulencia: 4, Cofio:4, Guadalix: 4, Guadarrama: 10, Henares: 4, Jarama 25, Lozoya 5, Manzanares: 8, Perales 3, Tajo 16, Tajuña 12 and Torote 3.

The result of this weighting process is shown in the following table. The final scores assigned to the categories of the variables differ in some cases in the various zones in the study area (evaporitic, mountain area and foothills).

In the selected scoring/weighting system, 1 represents the best value and $n$ the worst value. (Table 1).

The result of this weighting process is shown in the following table. 
TABle 1

RESULT OF THE WEIGHTING PROCESS

\begin{tabular}{|c|c|c|c|c|c|c|c|}
\hline & & & & & Category val & & \\
\hline & & $\mathrm{ab}$ & & $\mathrm{K}$ & Evaporitic & Mountains & Foothills \\
\hline River and & 1 & & Width of river & 2 & & & \\
\hline banks & & 1 & $<5 \mathrm{~m}$ & & 3 & 3 & 3 \\
\hline & & 2 & $5-20 \mathrm{~m}$ & & 2 & 2 & 2 \\
\hline & & 3 & $>20 \mathrm{~m}$ & & 1 & 1 & 1 \\
\hline & 2 & & Average central depth & 3 & & & \\
\hline & & 1 & $<0.6 \mathrm{~m}$ & & 3 & 3 & 3 \\
\hline & & 2 & $0.6-1.5 \mathrm{~m}$ & & 1 & 1 & 1 \\
\hline & & 3 & $>1.5 \mathrm{~m}$ & & 2 & 2 & 3 \\
\hline & 3 & & Riverbed materials & 2 & & & \\
\hline & & 1 & Rocky riverbed & & 0 & 2 & 2 \\
\hline & & 2 & Clay and silt & & 3 & 5 & 5 \\
\hline & & 3 & Sandy riverbed & & 0 & 1 & 1 \\
\hline & & 4 & Gravel riverbed & & 1.5 & 3.5 & 3.5 \\
\hline & & 5 & Pebble riverbed & & 1.5 & 3.5 & 3.5 \\
\hline & 4 & & Riverbank geometry & 2 & & & \\
\hline & & 1 & Vertical banks & & 3 & 3 & 3 \\
\hline & & 2 & Gently-sloping banks & & 2 & 2 & 2 \\
\hline & & 3 & $\begin{array}{l}\text { River and banks at } \\
\text { practically the same level }\end{array}$ & & 1 & 1 & 1 \\
\hline & & & & & & & \\
\hline
\end{tabular}

Estudios Geográficos, Vol. LXXVI, 279, pp. 633-670, julio-diciembre 2015 ISSN: 0014-1496, eISSN: 1988-8546, doi: 10.3989/estgeogr.201523 


\begin{tabular}{|c|c|c|c|c|c|c|}
\hline & & & & \multicolumn{3}{|c|}{ Category value } \\
\hline \multicolumn{3}{|c|}{ Variable } & K & Evaporitic & Mountains & Foothills \\
\hline \multirow[t]{6}{*}{5} & & Current & 2 & & & \\
\hline & 1 & Scarce or none & & 4.5 & 4.5 & 4.5 \\
\hline & 2 & Medium - scarce & & 2.5 & 2.5 & 2.5 \\
\hline & 3 & Medium & & 1 & 1 & 1 \\
\hline & 4 & Medium - strong & & 2.5 & 2.5 & 2.5 \\
\hline & 5 & Strong & & 4.5 & 4.5 & 4.5 \\
\hline \multirow[t]{5}{*}{6} & & $\begin{array}{l}\text { Type of riparian } \\
\text { vegetation }\end{array}$ & 2 & & & \\
\hline & 1 & Emergent plants & & 2 & 3 & 3 \\
\hline & 2 & Rooted plants & & 0 & 1 & 1 \\
\hline & 3 & Free-floating & & 0 & 0 & 0 \\
\hline & 4 & Submerged & & 1 & 2 & 2 \\
\hline \multirow[t]{5}{*}{7} & & Abundance & 3 & & & \\
\hline & 1 & Continuous & & 0 & 0 & 4 \\
\hline & 2 & Discontinuous & & 3 & 0 & 3 \\
\hline & 3 & Clumps & & 2 & 2 & 2 \\
\hline & 4 & Scarce & & 1 & 1 & 1 \\
\hline \multirow[t]{4}{*}{8} & & $\begin{array}{l}\text { Geomorphological } \\
\text { processes on the banks }\end{array}$ & 1 & & & \\
\hline & 1 & Erosion gullies & & 0 & 0 & 0 \\
\hline & 2 & Landslides & & 2 & 2 & 1 \\
\hline & 3 & Crevices & & 1 & 1 & 0 \\
\hline
\end{tabular}




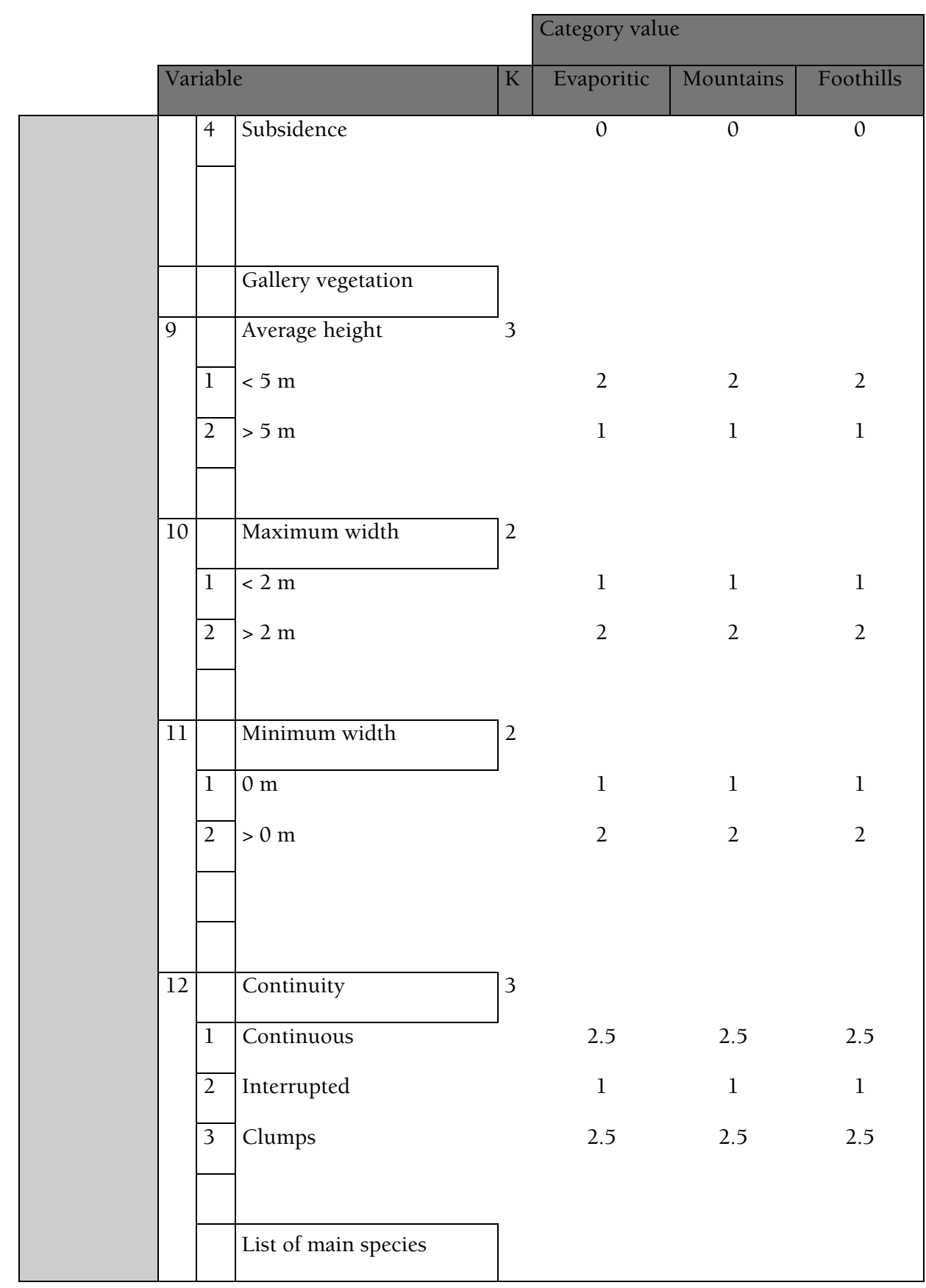

Estudios Geográficos, Vol. LXXVI, 279, pp. 633-670, julio-diciembre 2015 ISSN: 0014-1496, eISSN: 1988-8546, doi: 10.3989/estgeogr.201523 


\begin{tabular}{|c|c|c|c|c|c|c|}
\hline & & & & \multicolumn{3}{|c|}{ Category value } \\
\hline \multicolumn{3}{|c|}{ Variable } & K & Evaporitic & Mountains & Foothills \\
\hline \multirow[t]{10}{*}{13} & & Trees & 3 & & & \\
\hline & 1 & Populus sp. & & 1 & 2.5 & 2 \\
\hline & 2 & Salix sp. & & 5 & 6 & 7 \\
\hline & 3 & Fraxinus angustifolia & & 2 & 4 & 3,5 \\
\hline & 4 & Alnus glutinosa & & 0 & 1 & 1 \\
\hline & 5 & Ulmus minor & & 3 & 0 & 3,5 \\
\hline & 6 & Gen. Pinus & & 0 & 2.5 & 0 \\
\hline & 7 & Robina pseudoacacia & & 0 & 0 & 6 \\
\hline & 8 & Gen. Quercus & & 0 & 5 & 5 \\
\hline & 9 & Tamarix & & 4 & 0 & 0 \\
\hline \multirow[t]{12}{*}{14} & & Shrubs & 3 & & & \\
\hline & 1 & Populus sp. & & 2 & 5 & 2 \\
\hline & 2 & Salix sp. & & 4 & 7 & 4 \\
\hline & 3 & Tamarix sp. & & 2 & 0 & 0 \\
\hline & 4 & Rubus ulmifolius & & 6 & 9 & 6 \\
\hline & 5 & Rosa sp. & & 0 & 8 & 5 \\
\hline & 6 & $\begin{array}{l}\text { Phragmites australis, } \\
\text { Typha latifolia }\end{array}$ & & 5 & 0 & 0 \\
\hline & 7 & Retama sphaerocarpa & & 0 & 5 & 0 \\
\hline & 8 & Sambucus nigra & & 2 & 5 & 2 \\
\hline & 9 & Gen. Quercus & & 0 & 2 & 0 \\
\hline & 10 & Gen. Pinus & & 0 & 2 & 0 \\
\hline & 11 & Crataegus monogyna & & 0 & 2 & 0 \\
\hline
\end{tabular}




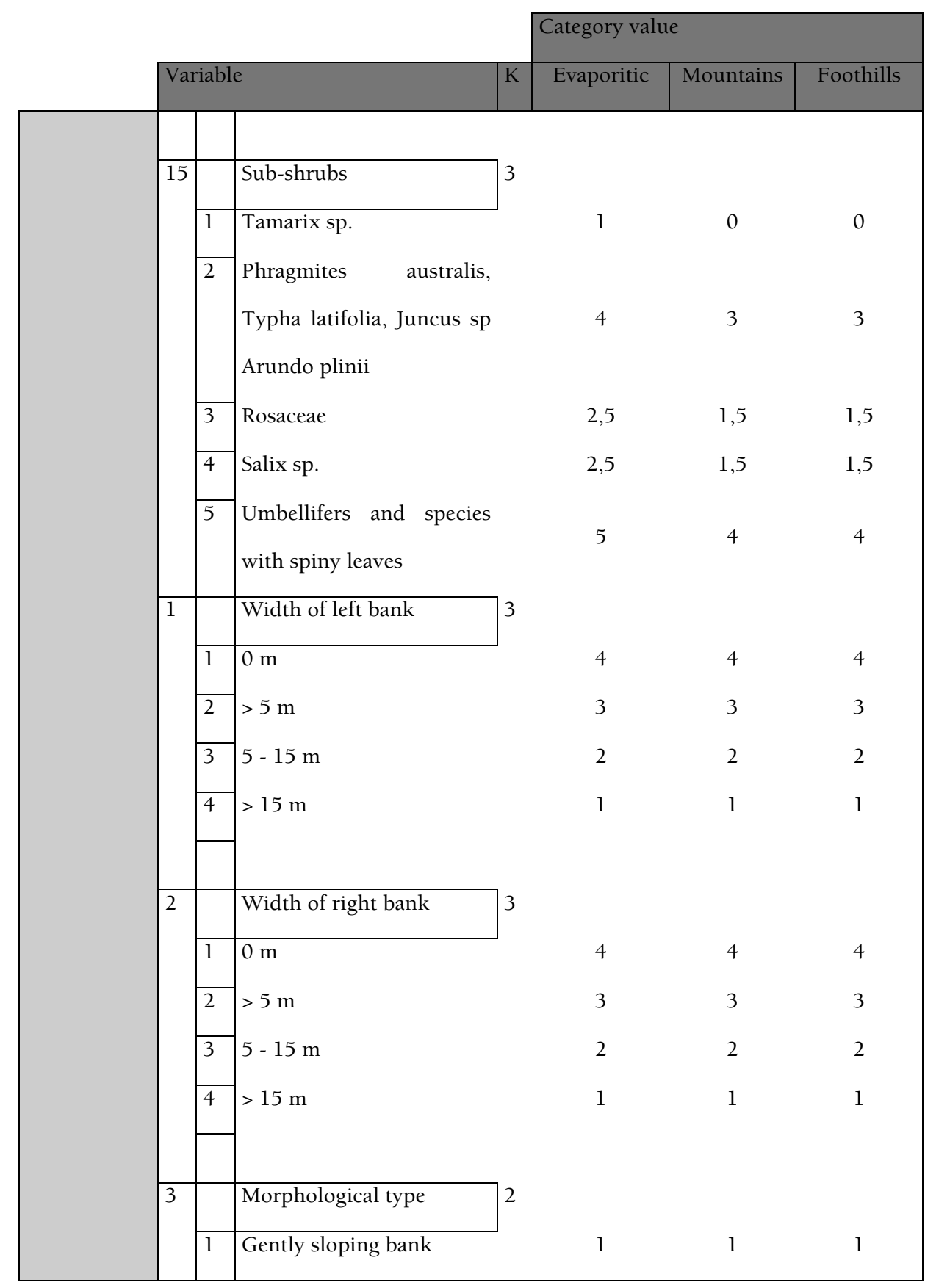

Estudios Geográficos, Vol. LXXVI, 279, pp. 633-670, julio-diciembre 2015 ISSN: 0014-1496, eISSN: 1988-8546, doi: 10.3989/estgeogr.201523 


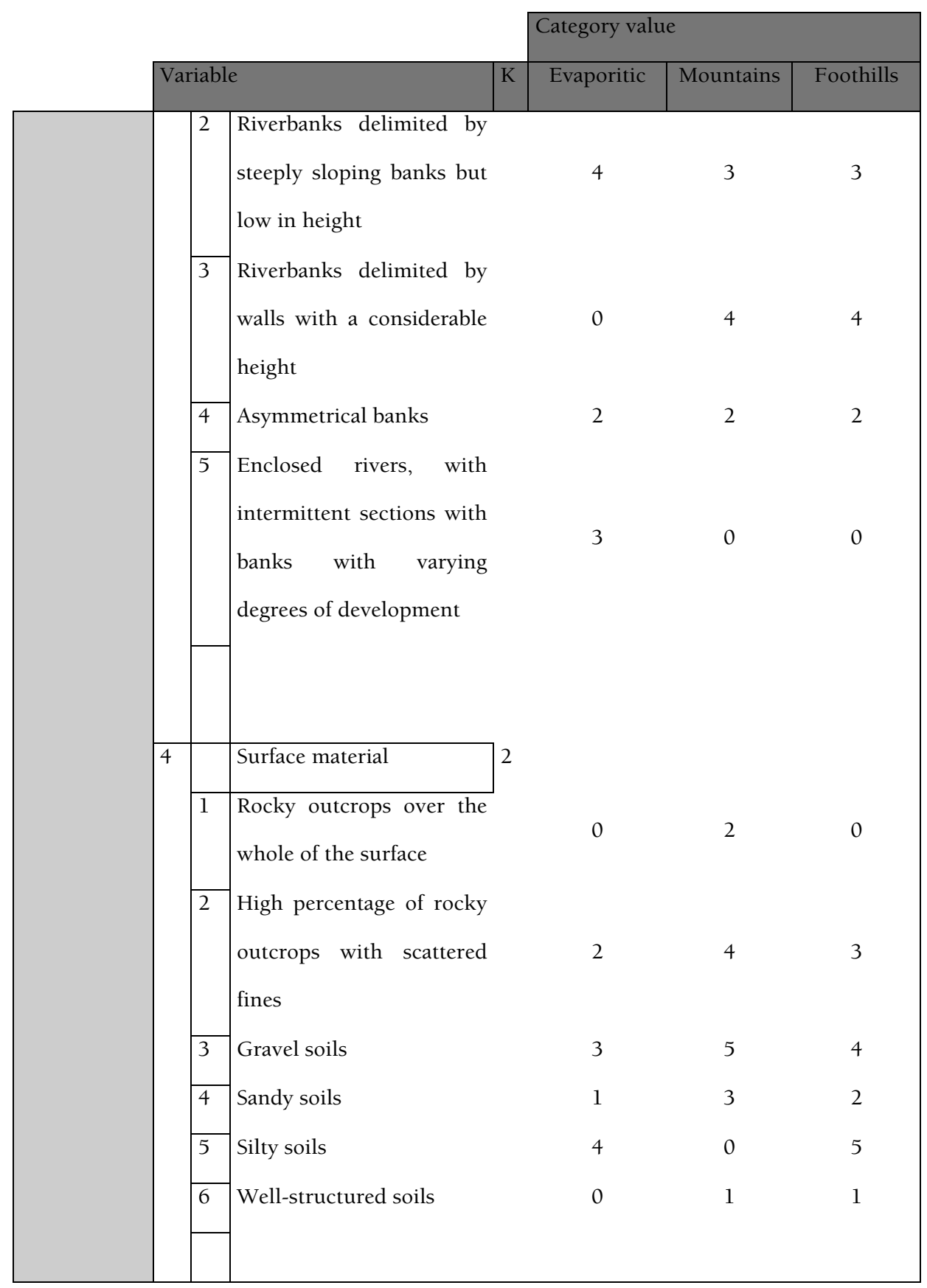




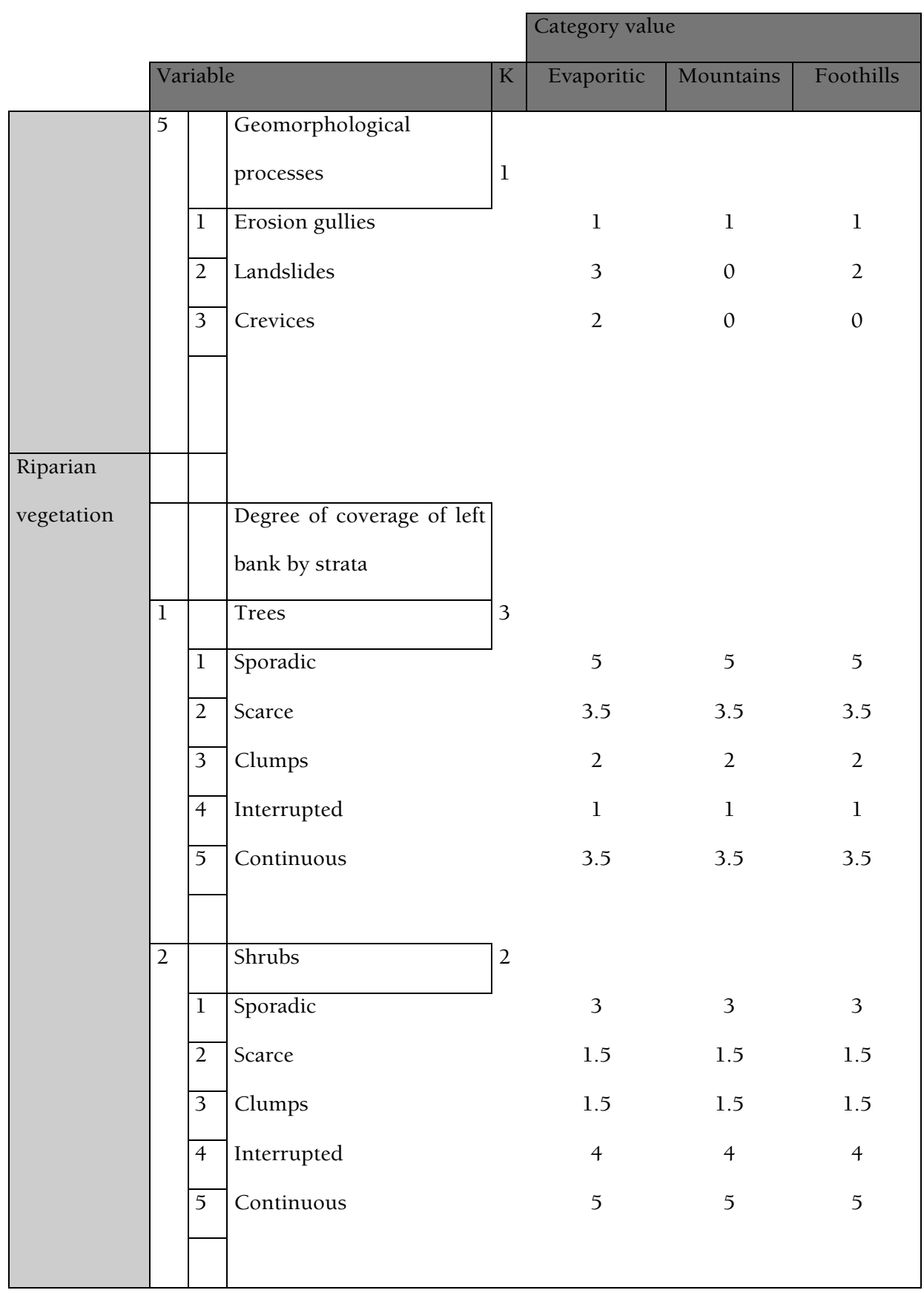

Estudios Geográficos, Vol. LXXVI, 279, pp. 633-670, julio-diciembre 2015 ISSN: 0014-1496, eISSN: 1988-8546, doi: 10.3989/estgeogr.201523 


\begin{tabular}{|c|c|c|c|c|c|c|}
\hline & & & & \multicolumn{3}{|c|}{ Category value } \\
\hline \multicolumn{3}{|c|}{ Variable } & K & Evaporitic & Mountains & Foothills \\
\hline \multirow[t]{6}{*}{3} & & Sub-shrubs & 1 & & & \\
\hline & 1 & Sporadic & & 1.5 & 3 & 3 \\
\hline & 2 & Scarce & & 0 & 1.5 & 1.5 \\
\hline & 3 & Clumps & & 1.5 & 1.5 & 1.5 \\
\hline & 4 & Interrupted & & 3 & 4 & 4 \\
\hline & 5 & Continuous & & 4 & 5 & 5 \\
\hline \multirow[t]{7}{*}{4} & 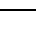 & Herbaceous & 2 & & & \\
\hline & 1 & Sporadic & & 5 & 5 & 5 \\
\hline & 2 & Scarce & & 4 & 4 & 4 \\
\hline & 3 & Clumps & & 3 & 3 & 3 \\
\hline & 4 & Interrupted & & 2 & 2 & 2 \\
\hline & 5 & Continuous & & 1 & 1 & 1 \\
\hline & & $\begin{array}{l}\text { Degree of coverage of } \\
\text { right bank by strata }\end{array}$ & & & & \\
\hline \multirow[t]{6}{*}{5} & & Trees & 3 & & & \\
\hline & 1 & Sporadic & & 4 & 5 & 5 \\
\hline & 2 & Scarce & & 2.5 & 2.5 & 2.5 \\
\hline & 3 & Clumps & & 1 & 2.5 & 2.5 \\
\hline & 4 & Interrupted & & 1 & 1 & 1 \\
\hline & 5 & Continuous & & 2.5 & 4 & 4 \\
\hline & & & & & & \\
\hline & & & & & & \\
\hline
\end{tabular}




\begin{tabular}{|c|c|c|c|c|c|c|}
\hline & & & & \multicolumn{3}{|c|}{ Category value } \\
\hline \multicolumn{3}{|c|}{ Variable } & $\mathrm{K}$ & Evaporitic & Mountains & Foothills \\
\hline \multirow[t]{6}{*}{6} & & Shrubs & 2 & & & \\
\hline & 1 & Sporadic & & 3 & 3 & 3 \\
\hline & 2 & Scarce & & 1.5 & 1.5 & 1.5 \\
\hline & 3 & Clumps & & 1.5 & 1.5 & 1.5 \\
\hline & 4 & Interrupted & & 4 & 4 & 4 \\
\hline & 5 & Continuous & & & & \\
\hline \multirow[t]{6}{*}{7} & & Sub-shrubs & 1 & & & \\
\hline & 1 & Sporadic & & 3 & 3 & 3 \\
\hline & 2 & Scarce & & 1.5 & 1.5 & 1.5 \\
\hline & 3 & Clumps & & 1.5 & 1.5 & 1.5 \\
\hline & 4 & Interrupted & & 4 & 4 & 4 \\
\hline & 5 & Continuous & & 4 & 5 & 5 \\
\hline \multirow[t]{6}{*}{8} & & Herbaceous & 2 & & & \\
\hline & 1 & Sporadic & & 5 & 0 & 0 \\
\hline & 2 & Scarce & & 4 & 0 & 4 \\
\hline & 3 & Clumps & & 3 & 3 & 3 \\
\hline & 4 & Interrupted & & 2 & 2 & 2 \\
\hline & 5 & Continuous & & 1 & 1 & 1 \\
\hline \multirow[t]{2}{*}{9} & & $\begin{array}{l}\text { Degree of total coverage } \\
\text { of left bank }\end{array}$ & 2 & & & \\
\hline & 1 & Sporadic & & 4 & 0 & 0 \\
\hline
\end{tabular}

Estudios Geográficos, Vol. LXXVI, 279, pp. 633-670, julio-diciembre 2015 ISSN: 0014-1496, eISSN: 1988-8546, doi: 10.3989/estgeogr.201523 


\begin{tabular}{|c|c|c|c|c|c|c|}
\hline & & & & \multicolumn{3}{|c|}{ Category value } \\
\hline \multicolumn{3}{|c|}{ Variable } & K & \multirow{2}{*}{$\begin{array}{c}\text { Evaporitic } \\
0\end{array}$} & \multirow{2}{*}{$\begin{array}{c}\text { Mountains } \\
0\end{array}$} & \multirow{2}{*}{$\begin{array}{c}\text { Foothills } \\
4\end{array}$} \\
\hline & 2 & Scarce & & & & \\
\hline & 3 & Clumps & & 3 & 0 & 3 \\
\hline & 4 & Interrupted & & 2 & 2 & 2 \\
\hline & 5 & Continuous & & 1 & 1 & 1 \\
\hline \multirow[t]{7}{*}{10} & & $\begin{array}{l}\text { Degree of total coverage } \\
\text { of right bank }\end{array}$ & 2 & & & \\
\hline & 1 & Sporadic & & 4 & 0 & 0 \\
\hline & 2 & Scarce & & 0 & 0 & 4 \\
\hline & 3 & Clumps & & 3 & 0 & 3 \\
\hline & 4 & Interrupted & & 2 & 2 & 2 \\
\hline & 5 & Continuous & & 1 & 1 & 1 \\
\hline & & $\begin{array}{l}\text { List of main species by } \\
\text { strata }\end{array}$ & & & & \\
\hline \multirow[t]{9}{*}{11} & & Tree & 3 & & & \\
\hline & 1 & Populus sp. & & 2.5 & 2.5 & 2.5 \\
\hline & 2 & Salix sp. & & 6 & 9 & 6 \\
\hline & 3 & Fraxinus angustifolia & & 2.5 & 2.5 & 2.5 \\
\hline & 4 & Alnus glutinosa & & 0 & 1 & 1 \\
\hline & 5 & Ulmus minor & & 1 & 2 & 2 \\
\hline & 6 & Pinus halepensis & & 5 & 0 & 0 \\
\hline & 7 & Pinus pinaster & & 0 & 5.5 & 0 \\
\hline & 8 & Pinus pinea & & 0 & 0 & 0 \\
\hline
\end{tabular}




\begin{tabular}{|c|c|c|c|c|c|c|}
\hline & & & & \multicolumn{3}{|c|}{ Category value } \\
\hline \multicolumn{3}{|c|}{ Variable } & K & Evaporitic & Mountains & Foothills \\
\hline & 9 & Pinus sylvestris & & 4 & 5.5 & 0 \\
\hline & 10 & Quercus ilex & & 0 & 8 & 5 \\
\hline & 11 & Quercus pyrenaica & & 0 & 7 & 0 \\
\hline & 12 & Ailantus altissima & & 0 & 10 & 7 \\
\hline & 13 & Other & & 7 & 11 & 0 \\
\hline \multirow[t]{12}{*}{12} & & Shrubs & 2 & & & \\
\hline & 1 & Populus sp & & 3 & 4.5 & 4.5 \\
\hline & 2 & Salix sp. & & 5 & 9 & 8 \\
\hline & 3 & Tamarix sp. & & 3 & 4.5 & 3.5 \\
\hline & 4 & Rubus ulmifolius & & 6 & 10 & 9 \\
\hline & 5 & Rosa sp. & & 0 & 8 & 7 \\
\hline & 6 & Retama sphaerocarpa & & 3 & 6 & 5 \\
\hline & 7 & Cistus ladanifer & & 0 & 7 & 6 \\
\hline & 8 & Sambucus nigra & & 0 & 2 & 2 \\
\hline & 9 & Crataegus monogyna & & 1 & 1 & 1 \\
\hline & 10 & Erica arborea & & 0 & 3 & 0 \\
\hline & 11 & Crops & & 0 & 0 & 0 \\
\hline \multirow[t]{4}{*}{13} & & Sub-shrubs & 3 & & & \\
\hline & 1 & $\begin{array}{l}\text { Reeds, rushes, bulrushes, } \\
\text { reed grasses }\end{array}$ & & 2 & 4 & 3 \\
\hline & 2 & Rosaceae & & 1 & 2 & 1 \\
\hline & 3 & Lavender and thyme & & 0 & 3 & 2 \\
\hline
\end{tabular}

Estudios Geográficos, Vol. LXXVI, 279, pp. 633-670, julio-diciembre 2015 ISSN: 0014-1496, eISSN: 1988-8546, doi: 10.3989/estgeogr.201523 


\begin{tabular}{|c|c|c|c|c|c|c|c|}
\hline & & & & & \multicolumn{3}{|c|}{ Category value } \\
\hline & \multicolumn{3}{|c|}{ Variable } & $\mathrm{K}$ & \multirow[t]{2}{*}{ Evaporitic } & \multirow[t]{2}{*}{ Mountains } & \multirow[t]{2}{*}{ Foothills } \\
\hline & & & thickets & & & & \\
\hline & & 4 & Nettles & & 0 & 4.5 & 4.5 \\
\hline & & 5 & $\begin{array}{l}\text { Umbellifers and species } \\
\text { with spiny leaves }\end{array}$ & & 3 & 5.5 & 4.5 \\
\hline & & 6 & Ferns & & 0 & 1 & 0 \\
\hline \multirow[t]{10}{*}{ Current state } & & & & & & & \\
\hline & 1 & & $\begin{array}{l}\text { Degree of deterioration of } \\
\text { the riverbank }\end{array}$ & 3 & & & \\
\hline & & 1 & Severe deterioration & & 3 & 4 & 4 \\
\hline & & 2 & Average deterioration & & 2 & 3 & 3 \\
\hline & & 3 & Slight deterioration & & 1 & 2 & 2 \\
\hline & & 4 & No deterioration & & 0 & 1 & 1 \\
\hline & 2 & & $\begin{array}{l}\text { Diversity of the plant } \\
\text { landscape on the } \\
\text { riverbank as a whole }\end{array}$ & 2 & & & \\
\hline & & 1 & $\begin{array}{l}\text { Landscape rich in a } \\
\text { variety of species, heights, } \\
\text { colours }\end{array}$ & & 1 & 1 & 1 \\
\hline & & 2 & $\begin{array}{l}\text { Landscape fairly rich in } \\
\text { variety, heights, colours }\end{array}$ & & 2 & 2 & 2 \\
\hline & & 3 & Less rich landscape & & 3 & 3 & 3 \\
\hline
\end{tabular}




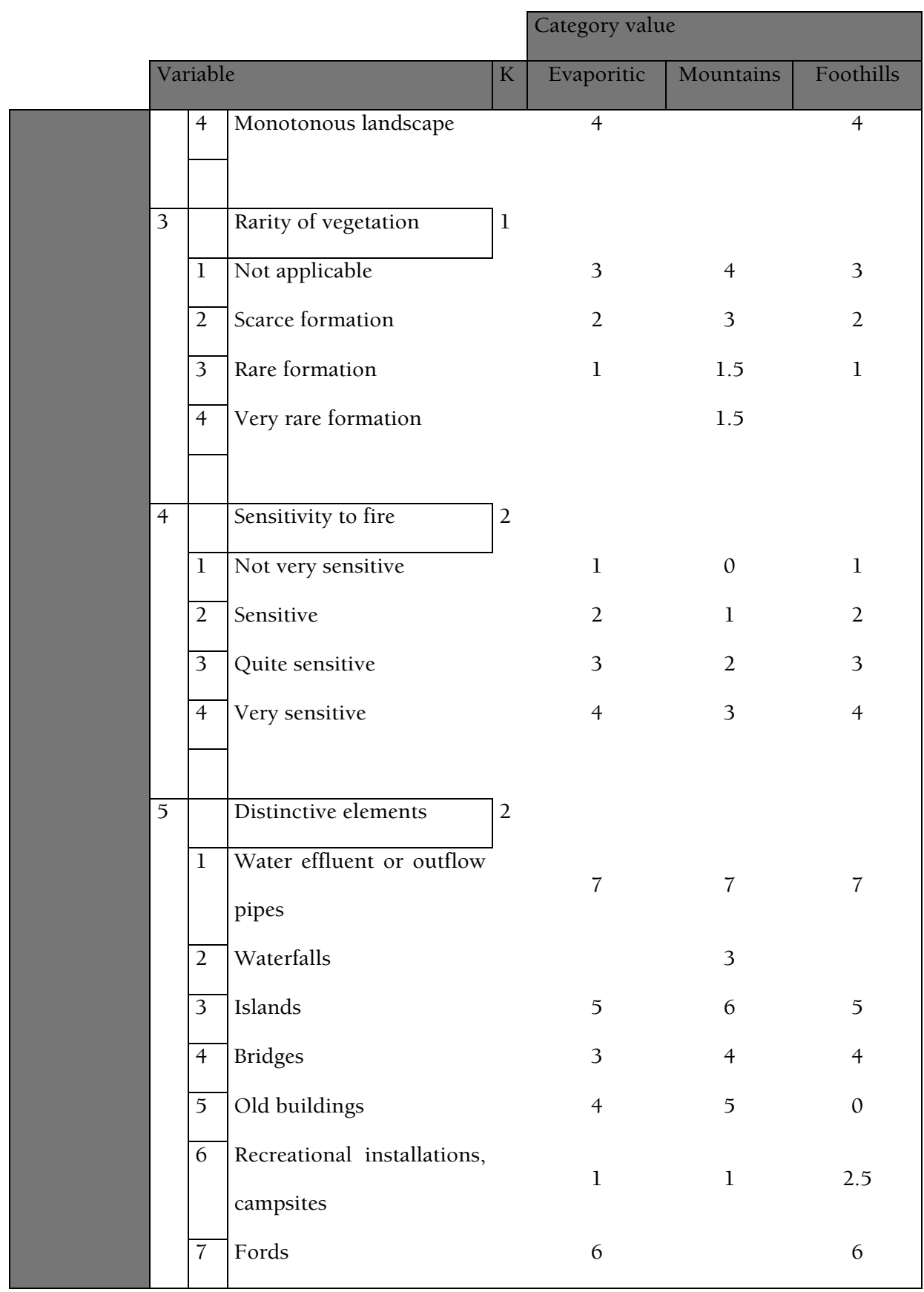

Estudios Geográficos, Vol. LXXVI, 279, pp. 633-670, julio-diciembre 2015 ISSN: 0014-1496, eISSN: 1988-8546, doi: 10.3989/estgeogr.201523 


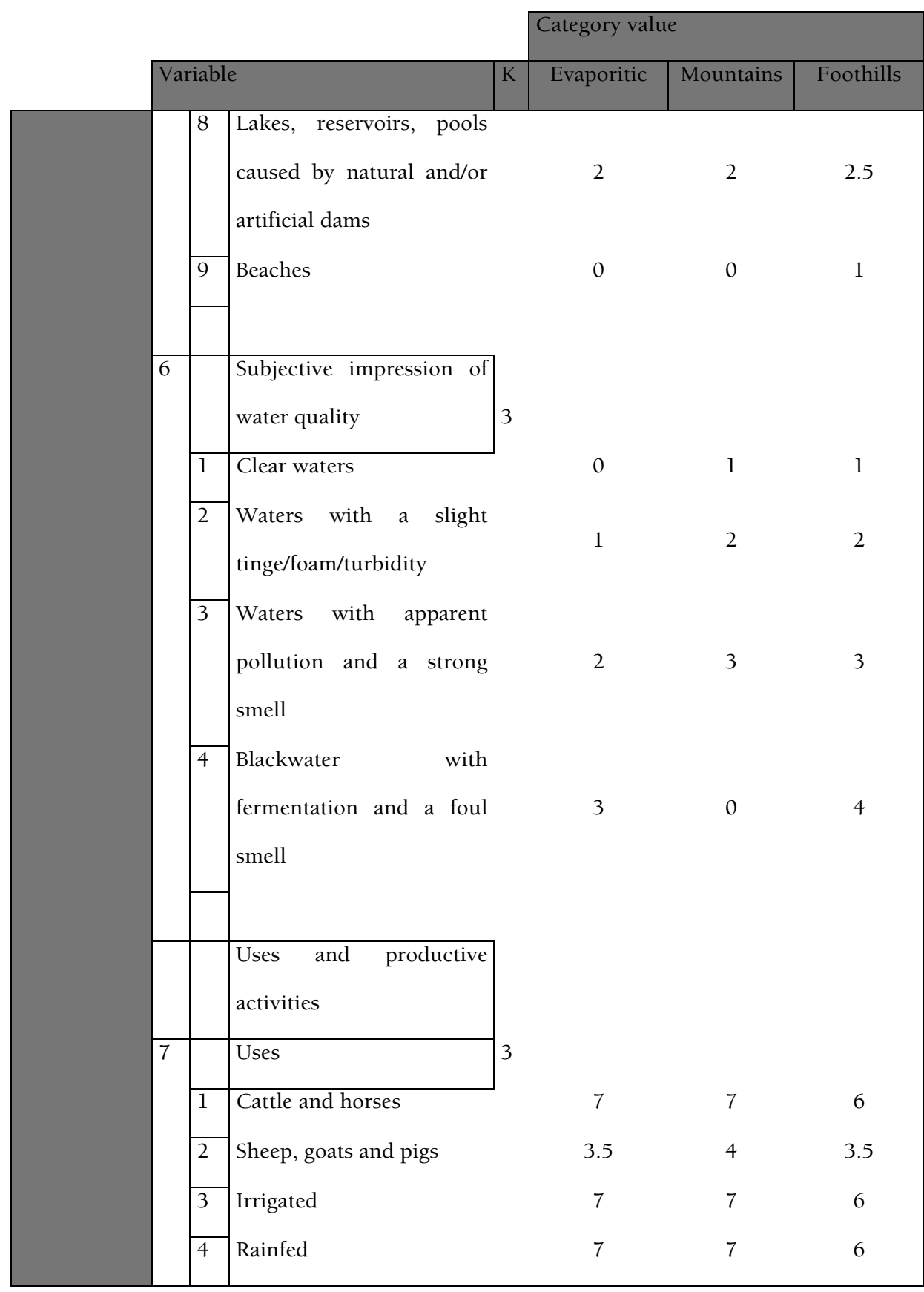




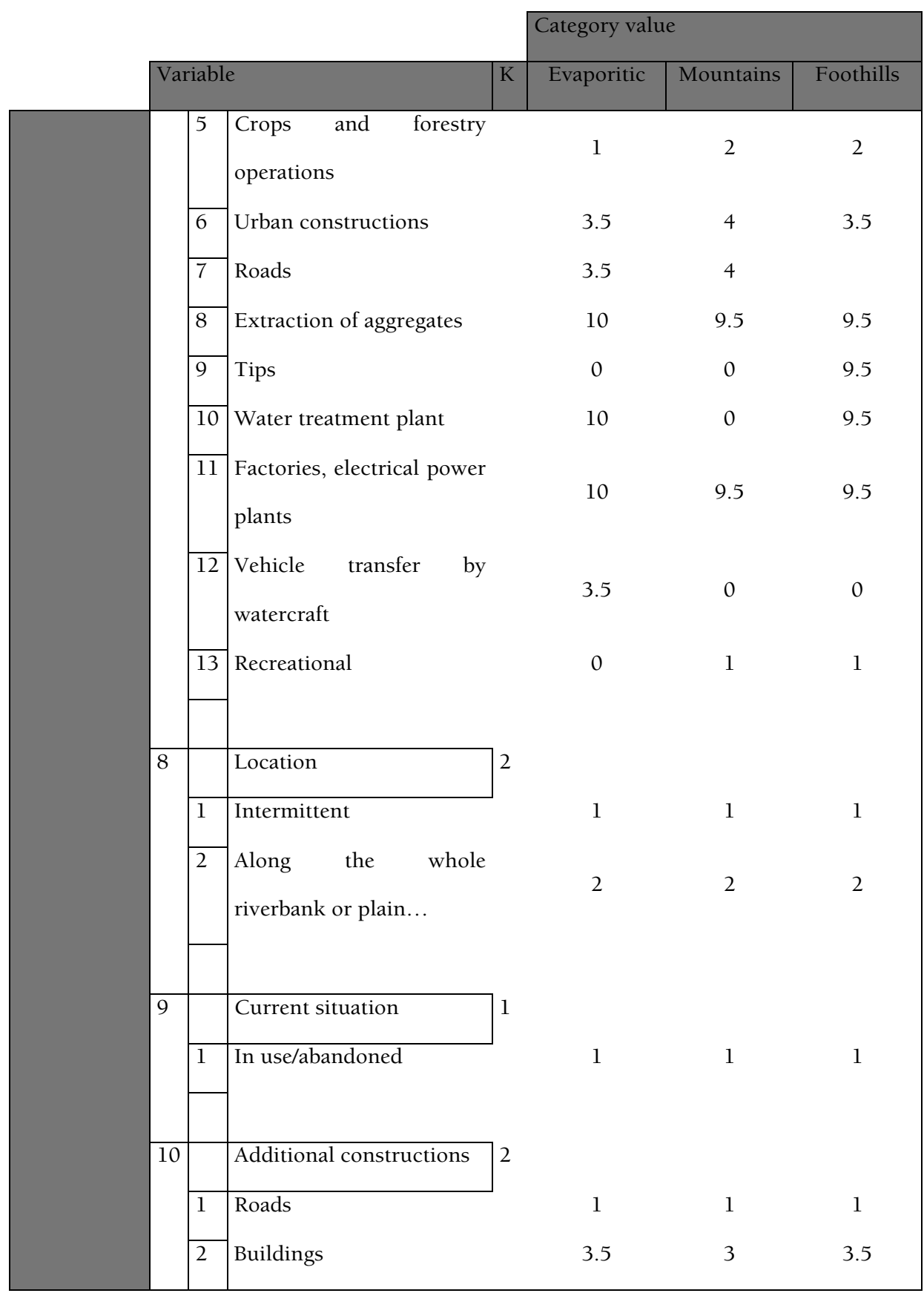

Estudios Geográficos, Vol. LXXVI, 279, pp. 633-670, julio-diciembre 2015 ISSN: 0014-1496, eISSN: 1988-8546, doi: 10.3989/estgeogr.201523 


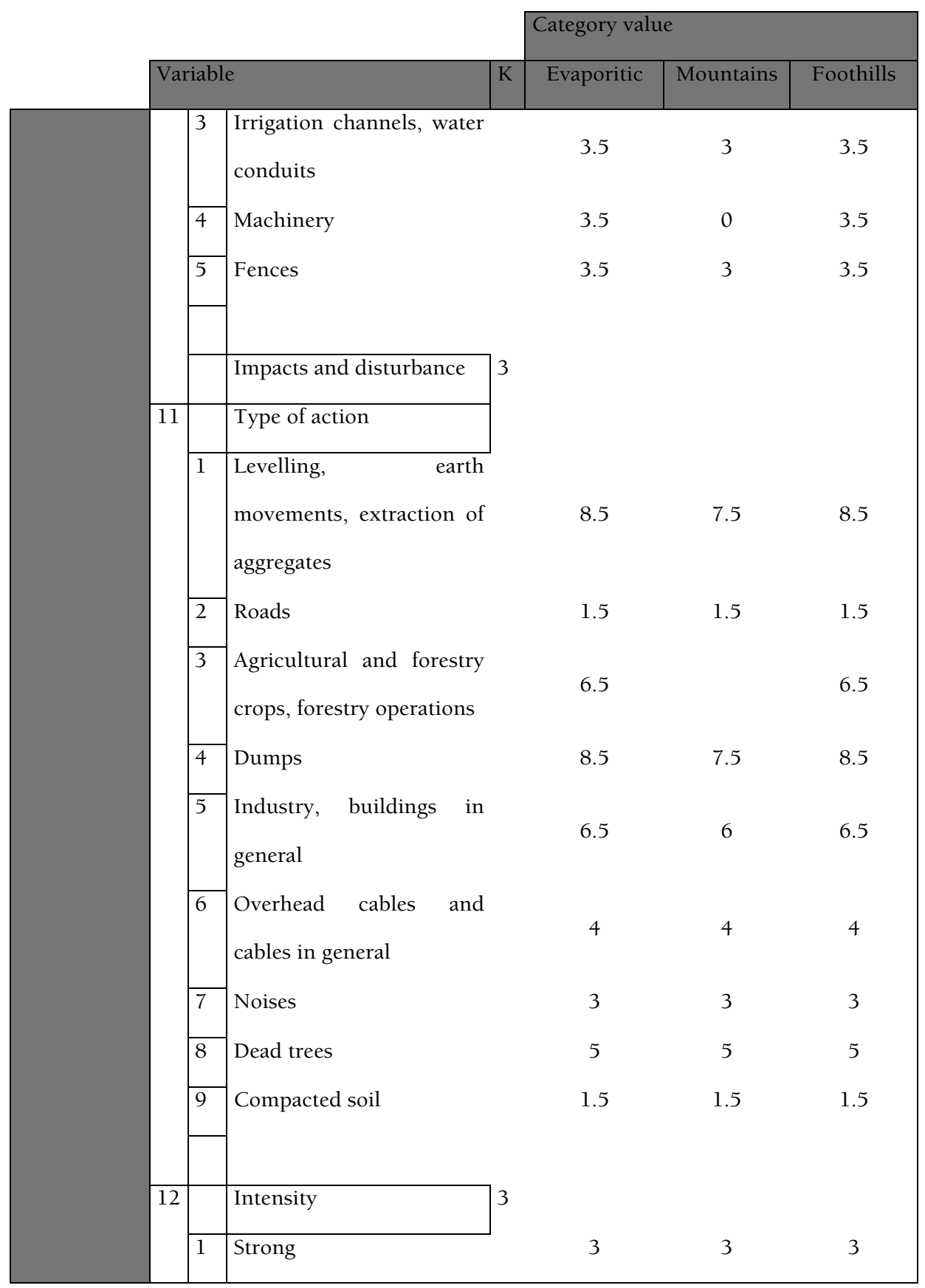




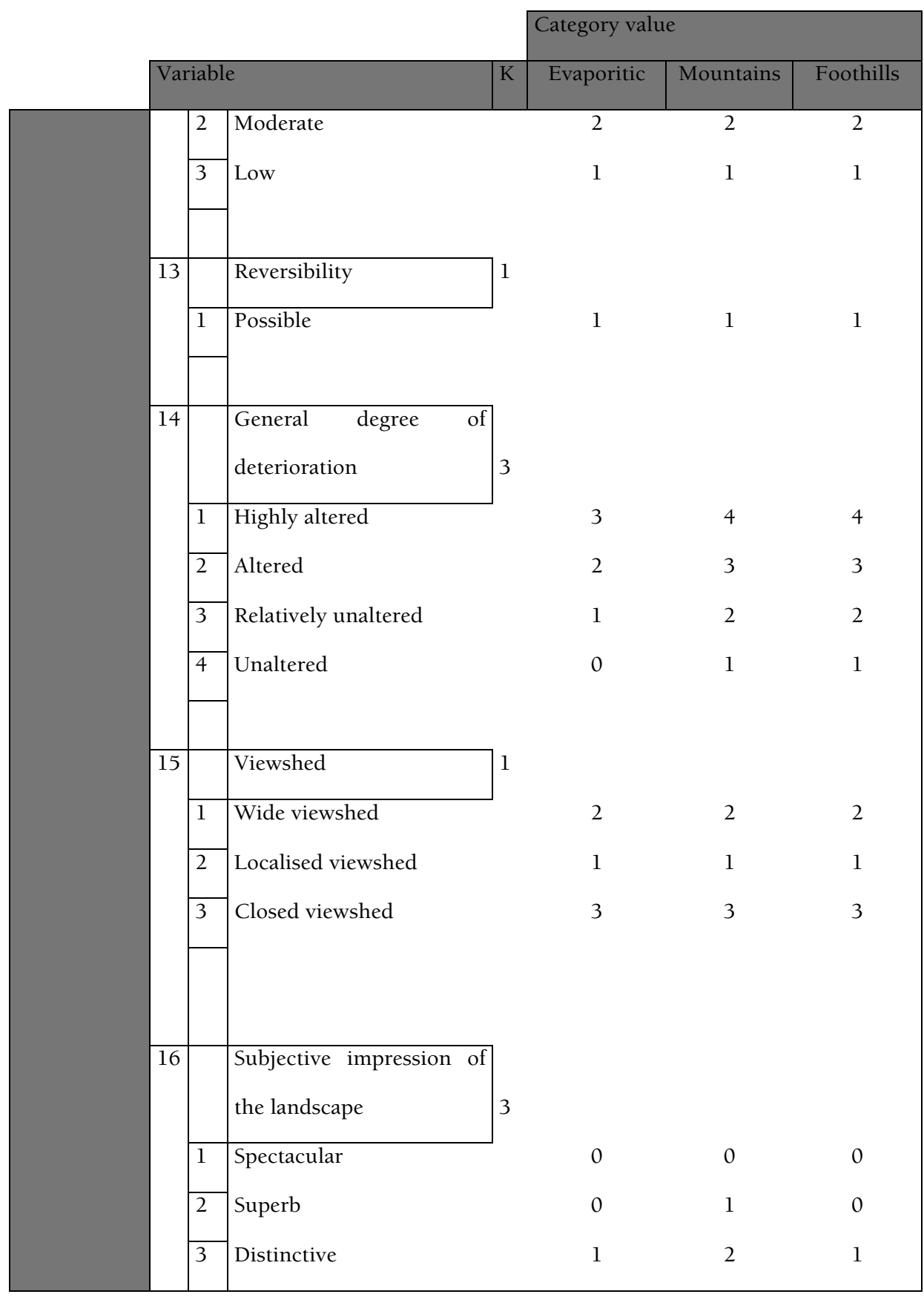

Estudios Geográficos, Vol. LXXVI, 279, pp. 633-670, julio-diciembre 2015 ISSN: 0014-1496, eISSN: 1988-8546, doi: 10.3989/estgeogr.201523 


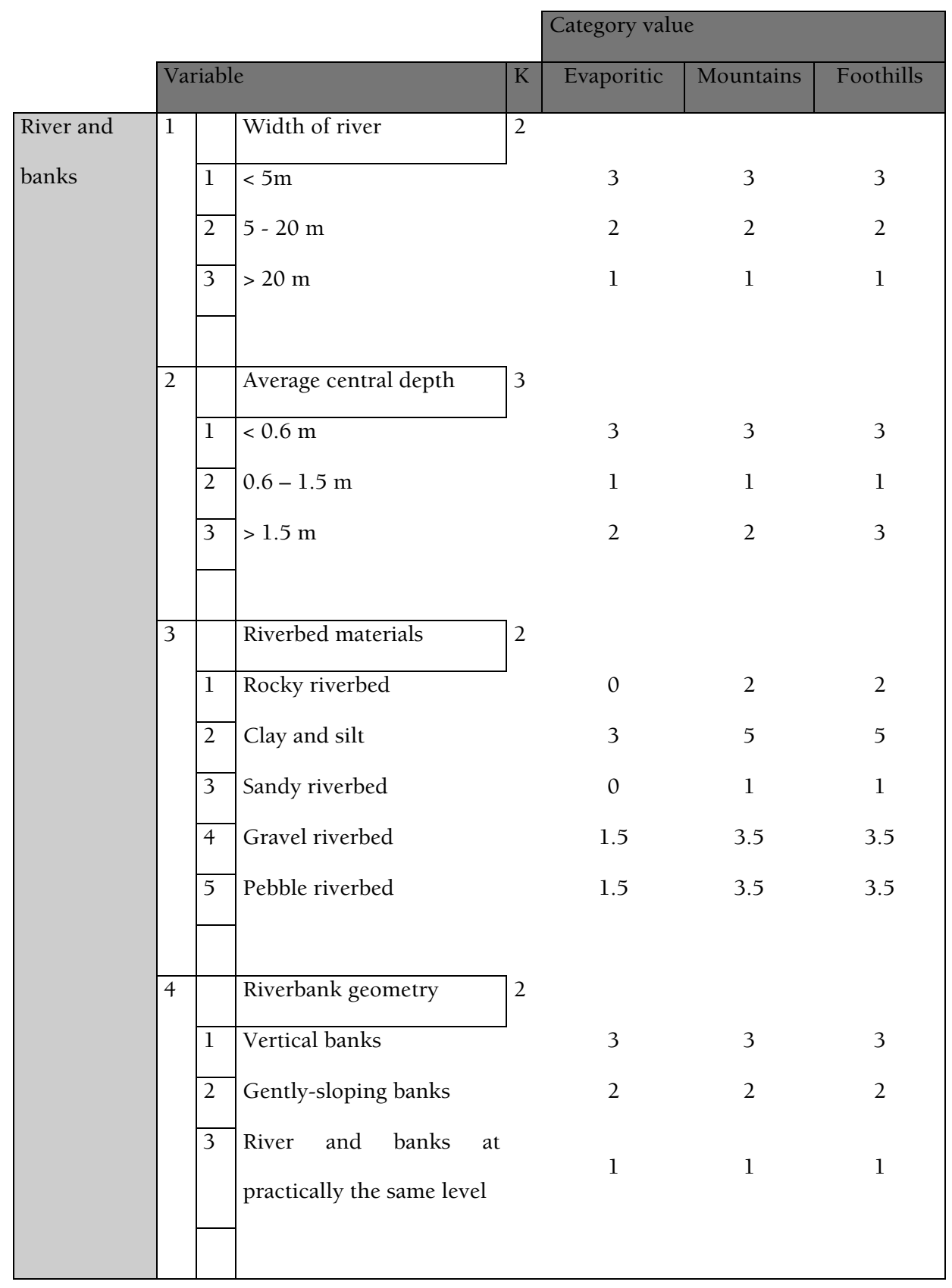

Origin: Own production. 


\section{INTEGRACION}

Numerous multi-criteria decision rules have traditionally been used in the area of planning. For our study we have chosen the weighted linear sum. In this technique the decision-maker assigns a series of weights -indicating relative importance- to each variable and a series of values to the different classes of categories; then the total score for each alternative is calculated (plot or point in the territory) according to the following formula:

$$
\text { CarringCapacity }=\sum_{\substack{i=1 \\ j=1}}^{n} k_{i} \cdot \boldsymbol{X}_{j}
$$

Where:

$$
\begin{aligned}
& \mathrm{x}_{\mathrm{i}} \text { : weight of each variable } \mathrm{i} \text {. } \\
& \mathrm{k}_{\mathrm{j}} \text { : value of category } \mathrm{j} \text {. }
\end{aligned}
$$

This method can conveniently be implemented in any raster and vector GIS model. The user should be aware that the weighted linear sum assumes two important principles: the linearity and additivity of the attributes, although these assumptions may sometimes be hazarded (Taboada and Cotos, 2005). GIS methods work with maps in which each element is associated to values in tables. Arithmetical operations can be done on these maps and tables, which in our case would be a weighted linear sum of the data associated to a map. The data for CAYO, MORR, VERI and ESAC associated to each plot is thus transformed into data on tourism and recreational attractiveness and sustainability, and is also able to represent this value spatially.

Finally, the resulting scores for each of the 103 plots are arranged into eight groups of load capacity scores according to the similarity of their characteristics in the variables considered.

\section{RESUltS}

The proposed method provides a valuation of the variables arranged in groups and weighted based on their capacity for recreational use according to the physiographic unit to which each plot belongs.

Each of these variables has been selected and characterised as suited for recreational use in terms of their biological and physical characteristics, land uses, aesthetic features, accessibility and water quality. 
The result of the whole process, as mentioned earlier, is the classification of the different plots considering their load or carrying capacity for recreational use.

By way of example, Table 2 shows the results for the plots in the mountain area.

TABLE 2

RESULTS FOR MOUNTAIN AREA PLOTS

\begin{tabular}{|c|c|c|c|c|c|c|c|c|}
\hline & Plot & $\begin{array}{l}\text { Sum } \\
\text { CAYO }\end{array}$ & $\begin{array}{c}\text { Sum } \\
\text { MORR }\end{array}$ & Sum VERI & $\begin{array}{l}\text { Sum } \\
\text { ESAC }\end{array}$ & Total & Interval & Group \\
\hline 1 & AU1 & 100 & 29 & 80 & 98.2 & 307.2 & $300-310$ & G4 \\
\hline 2 & AU2 & 88.9 & 22 & 72.5 & 91 & 274.4 & $270-290$ & G6 \\
\hline 3 & ALl & 76.5 & 41 & 0 & 96 & 213.5 & $<230$ & G8 \\
\hline 4 & AL2 & 80.9 & 28 & 88.7 & 99.2 & 296.8 & $290-300$ & G5 \\
\hline 5 & $\mathrm{Cl}$ & 105 & 32 & 92.1 & 92.6 & 321.7 & $320-330$ & G2 \\
\hline 6 & $\mathrm{C} 2$ & 102 & 35 & 106.5 & 79.6 & 323.1 & $320-330$ & G2 \\
\hline 7 & $\mathrm{C} 3$ & 97.3 & 32 & 89.1 & 106.8 & 325.2 & $320-330$ & G2 \\
\hline 8 & $\mathrm{C} 4$ & 79.8 & 25 & 72.6 & 92.1 & 269.5 & $230-270$ & G7 \\
\hline 9 & GX1 & 97.5 & 41 & 0 & 76.6 & 215.1 & $<230$ & G8 \\
\hline 10 & GX2 & 73.5 & 29 & 92.3 & 98.1 & 292.9 & $290-300$ & G5 \\
\hline 11 & GX3 & 74.2 & 28 & 86.1 & 108.7 & 297 & $290-300$ & G5 \\
\hline 12 & GM1 & 95.1 & 25 & 91.9 & 85 & 297 & $290-300$ & G5 \\
\hline 13 & GM2 & 102 & 19 & 80.5 & 109.5 & 311 & $310-320$ & G3 \\
\hline 14 & GM3 & 90.5 & 37 & 0 & 111 & 238.5 & $230-270$ & G7 \\
\hline 15 & J1 & 96.2 & 22 & 105 & 95.2 & 318.4 & $310-320$ & G3 \\
\hline 16 & $\mathrm{~J} 2$ & 97.7 & 27 & 94.4 & 67.5 & 286.6 & $230-270$ & G7 \\
\hline 17 & $\mathrm{~J} 3$ & 89.9 & 27 & 85.7 & 73.1 & 275.7 & $270-290$ & G6 \\
\hline 18 & J4 & 97.3 & 25 & 99.9 & 114.5 & 336.7 & $>330$ & Gl \\
\hline 19 & J5 & 93.3 & 25 & 71.1 & 94.5 & 283.9 & $270-290$ & G6 \\
\hline 20 & $\mathrm{Ll}$ & 81.4 & 31 & 81.8 & 76.6 & 270.8 & $270-290$ & G6 \\
\hline 21 & L2 & 84 & 17 & 79 & 94.6 & 274.6 & $270-290$ & G6 \\
\hline 22 & L3 & 87.5 & 33 & 91.1 & 91 & 302.6 & $300-310$ & G4 \\
\hline 23 & L4 & 96.5 & 31 & 94.1 & 87.6 & 309.2 & $300-310$ & G4 \\
\hline 24 & L5 & 91.3 & 21 & 84 & 108.1 & 304.4 & $300-310$ & G4 \\
\hline 25 & M3 & 89.1 & 32 & 89 & 88.7 & 298.8 & $290-300$ & G5 \\
\hline 26 & M4 & 95.5 & 24 & 96 & 92.6 & 308.1 & $300-310$ & G4 \\
\hline 27 & M5 & 95.5 & 31 & 112 & 96.8 & 335.3 & $>330$ & G1 \\
\hline
\end{tabular}

Origin: Own production. 
FIGURE 3

MAP OF RESULTS: PLOTS AND WATERCOURSES STUDIED
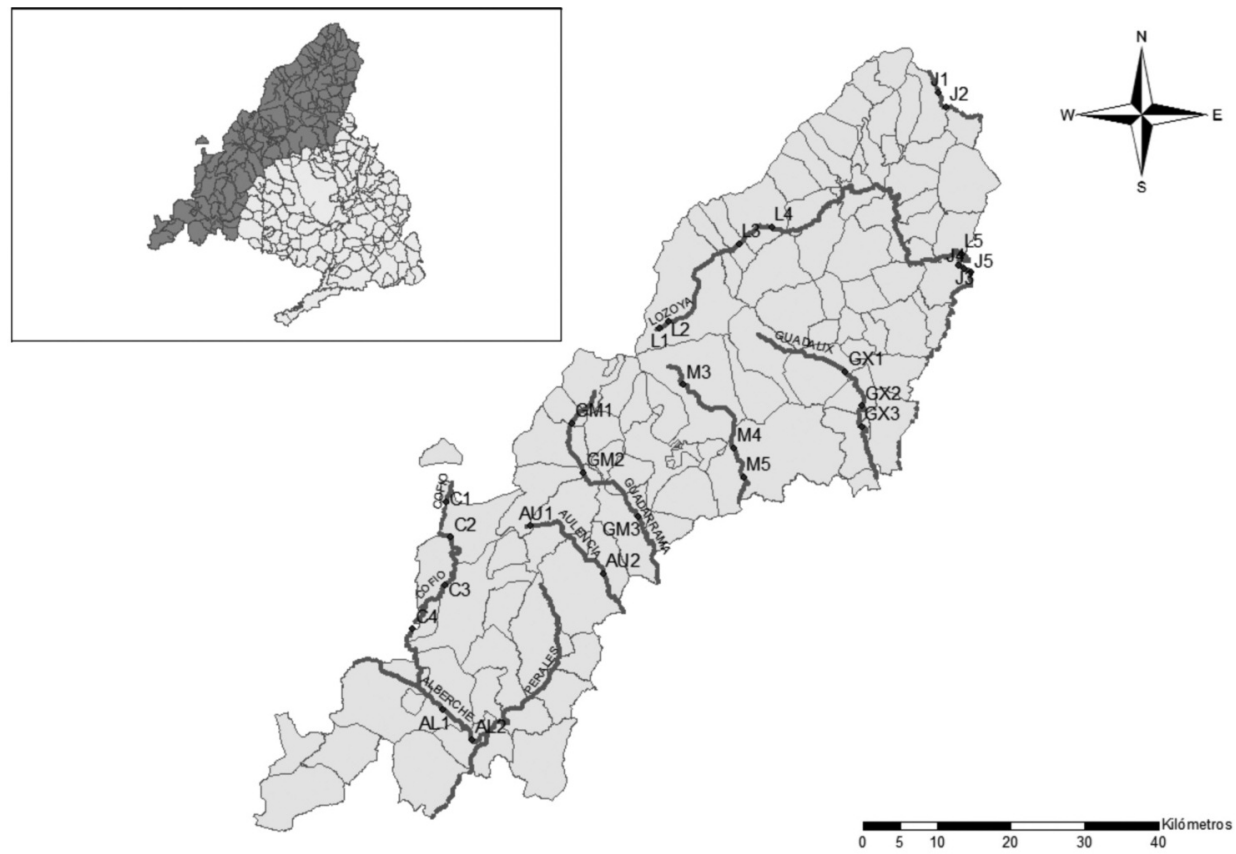

The final load capacity scores have been arranged in four groups with the intervals shown in Table 3.

TABLE 3

FINAL LOAD CAPACITY SCORES

- Group 1: > 330.

- Group 3: 310 - 320.

- Group 5: 290 - 300.

- Group 7: $230-270$.
- Group 2: 320 - 330.

- Group 4: $300-310$.

- Group 6: 270 - 290.

- Group 8: $<230$.

Origin: Own production. 
The contribution of the different variables to the final load capacity can be explained as follows:

CAYO: Rivers and shores are generally attractive for leisure; however the species there may be affected. This is not the case with elms, pseudoacacia, tamarinds, reeds and rushes. The most highly rated are broad river shores of over $20 \mathrm{~m}$ and an average depth of between 0.6 and $1.5 \mathrm{~m}$. Shores with a vertical geometry are less highly rated than those in which the riverbed and the bank are at the same level. An average current -neither very strong nor imperceptible- is most highly rated. Sandy beds are the most desirable, and gravel and pebbles the least. Parameters with a significant impact include the plant species in the gallery and their continuity and height.

MORR: the riverbank morphology in the mountain area is usually attractive and little affected by the impact of recreational use. Elements of interest include broad banks and gently sloping shores, or rivers that are intermittently hemmed in by their banks, in which there are sections where the banks are developed to a greater or lesser degree. The ideal surface material is silty soils, and the lowest-rated are rocky outcrops with scattered fines.

VERI: the species of plants, trees, shrubs and sub-shrubs are the categories that account for the highest scores in this matrix, and those which would suffer the greatest damage from the impact of recreational use. These include Ailiantus altissima, Salix sp. and others. In contrast, Pinus pinea is compatible with recreational use. Elms and farm crops are the least affected by recreational use.

ESAC: type of use and type of impact are the categories that have the greatest effect on the score, and produce the most significant differences in the final score. The uses contributing the lowest values concern the presence of factories and the extraction of aggregates, although livestock farming, irrigated and rainfed crops are also significant. The highest values come from recreational use. There are no significant types of impact or disturbance, and despite trampling and the presence of roads, they are generally not detrimental.

\section{DisCUSSION}

It is worth noting that the quality of the shores and riverbanks, gallery morphology and vegetation, riverbank morphology, riparian vegetation and current state can either increase the suitability for recreational use, or in many cases also decrease it due to the fact that less common or more sensitive species and morphologies are affected by recreational pressure. 
The most favourable results derive from a balance between withstanding this pressure and appealing to visitors.

Finally, to test the reliability of the proposed methodology, the sites in the mountain area were classified using a cluster classification method, the divisive-polythetic method. These methods are based on the theories of Hill (Hill et al., 1975) but continue to be wholly valid today (Kim and Billar et al., 2011). The sites were grouped into discriminatory parameters which were then classified and weighted based on their recreational potential, and the points obtained were clustered for their final classification.

The result is that both methods clearly differentiate the plots located in the extreme groups (very high or low carrying capacity), whereas those in the intermediate positions are less clearly defined.

There is a need to encourage society's interest in the landscape and involve the responsible politicians and the scientific community in the protection of urban, peri-urban and rural environments (Zarate, 2012).

The analysis of J. M. Fair (2010) describes an uneven exploitation of territorial resources and scant attention to issues of environmental sustainability, despite the proven richness of the territorial heritage.

\section{CONCLUSIONS}

This article proposes a method to assess the recreational capacity of riverbanks, taking into account the morphology of rivers and banks, gallery vegetation, riverbank morphology, riparian vegetation, uses and disturbances, landscape quality, water quality and accessibility, among others.

The use of this tool for evaluating recreational potential when planning vulnerable spaces such as riverbanks and shores was demonstrated to be effective, primarily because it achieves two of the key conditions that are required before embarking on a project to adapt these spaces for recreation:

- It defines concisely the carrying capacity of the selected area with regard to its use for recreational activities.

- It provides a scientific basis to assist in selecting the most appropriate management formula for these natural spaces.

- Finally, the comparison with the classification derived by applying the divisive-polythetic method confirms the reliability of the proposed methodology.

The assessment of recreational capacity is important when drafting ordination plans for natural resources. The choice of a good method for assessing 
this activity is essential for the planning and management of both protected natural spaces, and for anywhere this type of activity takes place. The ultimate aim is to offer satisfaction for visitors and ensure the minimum impact of recreational activity on these spaces.

Fecha de recepción: 26 de junio de 2014.

Fecha de aceptación: 19 de febrero de 2015.

\section{BIBLIOGRAPHY}

Asah et al. (2012): "Involving Forest Communities in Identifying and Constructing Ecosystem Services: Millennium Assessment and Place Specificity". Journal of Forestry, 110/3, pp. 149-156 (8).

Butler, R. (2006): "The tourism area life cycle", Ontario: Channel View, 1, pp 1-33.

Feria Toribio, J. M. (2010): "Patrimonio territorial y desarrollo sostenible un estudio comparativo en Iberoamérica y España". Estudios Geográficos, 71/268, pp. 129-159.

Garrigós Simón, F J. et al. (2004): "Carrying capacity in the tourism industry: a case study of Hengistbury Head". Tourism Management, 25/2, pp. 275-283.

Hill, M. O. et al. (1975): "Indicator species analysis. A divisive polythetic method of classification and its application of Native Pinewoods in Scotland". Journal of Ecology, 63, pp. 597-613.

Homan, M. A. and Bennett, J. T. (1973): "Determinants of use of water based recreational facilities". Water Resources Bulletin, 5, pp.1208-1218.

Hughes, G. (1995): "The cultural construction of sustainable tourism". Tourism Management, 16/1, pp.49-59.

Kim, J. and Billard, L. (2011): "A polythetic clustering process and cluster validity indexes for histogram - valued objects". Computational statistics and data analysis, 55/7, pp.2250-2262.

Kline et al. (2009): "Toward a Rational Exuberance for Ecosystem Services Markets". Journal of Forestry, 107/ 4, pp. 204-212 (9).

MacBeth, J. (2005): "Towards an ethics platform for tourism". Annals of Tourism Research, 32, pp. 962-965.

Manning et al. (1999): "Carrying Capacity Research for Yosemite Valley: Phase II", in: "Study. University of Vermont / Studies Lab. Burligton, Burlington, Park". Unpublished report

Manning et al. (2001): "Visitor Experience and Resource Protection: A Framework for Managing the Carrying Capacity of National Parks". Journal of Park and Recreation Administration, 19/1, pp. 39-108.

Manning et al. (2007): Parks and Carring Capacity: Commons Without Tragedy. Washington DC., Editorial IslandPress, pp 37-42. 
McCool, S. and Lime, D. (2001): "Tourism carrying capacity: tempting fantast or useful reality". Journal of Sustainable Tourism, 9, pp. 372-388.

Navarro, E. et al. (2012): "Carrying capacity assessment for tourist destinations. Methodology for the creation of synthetic indicators applied in a coastal area". Journal of Environmental Management, Touris Management, 33, pp. 1337-1346.

OMT Organización Mundial del Turismo (WTO, World Tourist Organization) (2005): Tourism s Potential as a Sustainable Development Strategy. Madrid, Spain, World Tourist Organization.

Prato T. (2001): "Modeling carrying capacity for national parks". Ecology.Economist, 39 , pp. 321-331.

Ritchie, J. R. B. and Crouch, G. I. (2004): The competitive destination. A sustainable tourism perspective. Oxon, UK, CABI Publishing.

Saarinen, J. (2006): "Traditions of sustainability in tourism studies". Annals of Tourism Research, 33/4, pp. 1121-1140.

Salerno, F. et al. (2013): "Multiple Carrying Capacities from a management-oriented perspective to operationalize sustainable tourism in protected areas". Journal of Environmental Management, Elsevier, 128, pp. 16-25.

Saveriades, A. (2000): "Establishing the social tourism carrying capacity for the tourists resorts of the east coast of the Republic of Cyprus". Tour. Manage, 21, pp. 147-156.

Selin, Steve et al. (2009): "Outdoor Recreation Research and Education for the $21^{\text {st }}$ Century: Defining National Direction and Building Capacity". Journal of Forestry, 107/7, pp. 346-349 (4).

Taboada, J. A. and Cotos J. M. (2005): Sistemas de información medioambiental. La Coruña, Netbiblo.

Urbiston, L. (1973): "El aprovechamiento recreativo de los embalses españoles". Revista de Obras Públicas, Julio, pp.18-23.

Valenzuela Rubio, M. (1989): "Los espacios para el ocio asociados al agua, o como Madrid añora el mar", en VV AA: Los paisajes del agua... Valencia, Univ. de Valencia/Univ. de Alicante, pp. 371-383. www.cbd.int, 2014. (Verified: 03/09/2015).

www.depi.vic.gov.au/forestry-and-land-use/forest-management/forest-managementplans, 2014. (Verified: 03/09/2015).

www.ecoturism.org, 2014.TIES, 2006. (Verified: 03/09/2015).

www.madrid.org/cs Comunidad de Madrid. 2013. Consejería de Medioambiente.

PIAM, Plan Forestal 2000 - 2019. Available on line. (Verified: 03/09/2015).

http://www.tennessee.gov/environment/, 2014. (Verified: 03/09/2015).

Zárate Martín, M. A. (2012): "Paisaje, forma y turismo en ciudades históricas". Estudios Geográficos, LXXIII/273, pp. 657-694. 


\section{RESUMEN}

El objetivo de este artículo es, determinar la capacidad de carga o acogida funcional, de asimilación y de recuperación de los márgenes y los cursos fluviales mediante la recopilación de información del medio; el potencial recreativo se evalúa además desde un doble punto de vista: ecológico y paisajístico.

La forma en que se enfoca el problema y se presenta la metodología y los resultados puede resultar de gran utilidad para planificadores y legisladores

La metodología propuesta para valorar el uso recreativo de los márgenes fluviales, se aplica a una serie de parcelas en la Comunidad de Madrid, teniendo en cuenta la satisfacción que la actividad produce en los usuarios, y la capacidad de carga o acogida del entorno en el que se desarrollan.

Como resultado, se presenta la valoración de parcelas piloto, que servirían para validar la metodología propuesta.

Palabras Clave: evaluación del turismo y del uso recreativo; capacidad de carga; riberas; suma lineal ponderada.

\section{AbSTRACT}

The aim of this article is to determine the load or functional carrying capacity for the assimilation and recovery of rivers and riverbanks by compiling information on the environment, and to assess the potential for recreation from the environmental and scenic point of view. We set out to find the most significant basis for analysing the pressures limiting carrying capacity and constraining the demand for recreational use. This methodology will help planners and legislators in their decision-making.

We also propose a methodology for assessing the recreational use of riverbanks, tested in a number of sites in the Madrid Region, in terms of the satisfaction the activity produces in the users, and the load or carrying capacity of the surrounding environment. A pilot site assessment is presented as a validation of the proposed methodology.

KEY WORDS: assessment of tourism and recreational use; riverbanks; carrying capacity; recreation tourism; linear weighted sum.

\section{RÉSUMÉ}

Le but de cet article est, déterminer la capacité de charge ou réception fonctionnelle, l'assimilation et rétablissement des marges et les cours de la rivière par le biais de la collecte d'informations de l'environnement: le potentiel récréatif est également évalué dans une double perspective: écologique et paysagère.

La façon dont se concentre le problème et présente la méthodologie et les résultats peut être utile pour les planificateurs et les décideurs.

La méthodologie proposée pour évaluer l'usage récréatif des marges de la rivière, s'applique à une série de parcelles dans la communauté de Madrid, tenant de l'activité compte satisfaction produit dans utilisateurs et la capacité de charge ou l'hôte de l'environnement dans lequel ils développent. 
Par conséquent, l'évaluation des parcelles pilotes, ce qui permettrait de valider la méthodologie proposée est présentée.

Mots CLÉs: évaluation de tourisme et d'utilisation des loisirs; des berges; la capacité de charge; les loisirs; le tourisme; la somme pondérée linéaire.

HighLigHTS

- We propose a method for the assessment of river bank tourism and recreational use.

- We determine carrying or load capacity for recreational use.

- We also present a pilot site assessment to validate the proposed methodology.

- The results were compared with the results obtained by applying a divisive-polythetic method. 